\title{
A Model for Organic Matter of Fields Fertilized with Anaerobic Digestion Reactor Effluent
}

\author{
Willem Jan Oosterkamp \\ Independent Scholar, Oosterbeek, Netherlands \\ Email address: \\ willemjan@ooosterkamp.org
}

To cite this article:

Willem Jan Oosterkamp. A Model for Organic Matter of Fields Fertilized with Anaerobic Digestion Reactor Effluent. American Journal of Modern Energy. Vol. 7, No. 5, 2021, pp. 75-81. doi: 10.11648/j.ajme.20210705.11

Received: May 17, 2021; Accepted: May 28, 2021; Published: October 30, 2021

\begin{abstract}
Soil fertility in agriculture is maintained by recalcitrant organic matter in manures and crop residues that are recycled to the fields. In some countries crop residues are burned in the field and in others these are collected and burned in furnaces as a source of renewable energy. These practices reduce the organic matter of the soils which is essential for their fertility. Anaerobic digestion installations convert manures and crop residues (mainly straw) into carbon dioxide, methane and other components. There remains a residue of recalcitrant organic material. The methane is is used as a source of renewable energy. The objective of this study is to determine the reduction in soil organic matter due to the anaerobic digestion of straw and cattle manure. The dynamics of the decay process of straw in the soil has been applied to the anaerobic digestion of these substrates. The decay of the organic material in the effluent of anaerobic digestion installations recycled to the fields has been modelled and compared to the decay of the substrates in the soil, without anaerobic digestion. The few field data on the effect of the effluent of anaerobic digestion reactor show no or little variation, compared to those when the substrates are directly applied to the fields. Around $45 \%$ of the energy content of straw and manures can be used as a source of renewable energy. The contribution to the soil organic matter of recycled effluent is $85 \%$ of that of the substrates directly applied to the soil.
\end{abstract}

Keywords: Soil Organic Matter, Renewable Energy, Anaerobic Digestion, Straw, Cattle Manure, Bio-methane

\section{Introduction}

Traditionally, crop residues are burned in the fields. Potassium and phosphate (fertilisers) in the ash are then directly available for the next crop [1]. Over the years, the soil organic matter [SOM] is reduced [2].

SOM in agricultural fields consists of decaying crop residues, roots and dead organisms [3, 4]. Archea, microbes and fungi transform this in carbon dioxide, water, and humic substances. SOM contains more carbon than global aboveground vegetation and the atmosphere combined $[5,6]$.

Nutrient exchanges between SOM, water, and soil are essential to soil fertility and need to be maintained. When the soil is exploited for crop production without restoring the organic matter and nutrient contents, the nutrient cycles are broken, soil fertility declines, and the balance in the agroecosystem is destroyed [7].

Currently, two thirds of the fields under maize and wheat cultivation have a SOM content of less than $2 \%$, the lower bound for optimal crop production [8]. Further reduction of
SOM in agricultural lands should thus be avoided.

The field burning of crop residues has stopped in some countries and is of a concern in others [9]. Straw, replacing coal, is instead burned or gasified in boilers and furnaces to generate heat and power $[10,11]$.

Various governments subside the building and operation of anaerobic digestion $[\mathrm{AD}]$ plants using organic materials from waste water clean-up, food processing and agricultural residues and energy crops [12-14]. The methane containing gas (biogas) is then burned in furnaces to produce heat and power. [15]. The AD of straw can replace the burning of straw as source of renewable energy renewable energy [16].

The German government requires bookkeeping of SOM. The guidelines suggest that using the effluent of $\mathrm{AD}$ reactors instead of straw and manure to fertilize the crops results longterm in a reduction of $50 \%$ in the SOM [17]. Newer research indicates, however, that $\mathrm{AD}$ has little effect on the SOM [18].

This paper describes a model for the SOM on fields fertilised with AD reactor effluent. This model assumes, that 
the decomposition process of organic material during $\mathrm{AD}$ is similar to that of the raw material in the fields.

\section{Anaerobic Digestion}

Anaerobic digestion is a naturally occurring process in swamps and is collected as heating or cooking fuel $[19,20]$. This process has been adapted to generate heat and power from treated wastewater, food processing residues, agricultural residues and manures. In $\mathrm{AD}$, organic matter or volatile solids (VS) is converted under exclusion of oxygen into carbon dioxide, methane, ammonia, sulphur dioxide and a number of other components. There remains a residue of water, ammonia, volatile acids and recalcitrant organic matter [21, 22].

The methane yield for different substrates can be determined by biomethane potential assays [BMP] [23, 24]. A BMP is performed by mixing the material with effluent from an operating $\mathrm{AD}$ reactor. The methane produced is measured at different times. An equation has been developed that describes the methane yield $\left(\mathrm{y}_{\mathrm{ch} 4}\right)$ in a BMP as a function of time using two exponential functions ( A fast component and a slow component).

$$
y_{C H 4=} a^{*}(1-R)^{*}\left(1-\left(-b^{*} c^{*} t\right)\right)+a^{*} R^{*}\left(1-e^{\left(-b^{*} d^{*} t\right)}\right)
$$

$\mathrm{a}=0.415 \mathrm{~m}^{3} / \mathrm{kg} \mathrm{VS}$, this is the theoretical methane yield for carbohydrates [25].

$\mathrm{b}=$ is a constant fitted to the BMP tests, reflecting the hydrolysis rate of the substrate

$\mathrm{c}=2.1 \mathrm{y}^{-1}$. is a multiplier to the the fast decay constant

$\mathrm{d}=0.13 \mathrm{y}^{-1}$. is a multiplier to the slow decay constant

$\mathrm{e}=2.72$ (natural logarithm)

$\mathrm{R}$ is the fraction of recalcitrant organic matter in the reactor substrate and fitted to the methane production curves in the BMP tests.

a-e and $\mathrm{R}$ are constants

$t$ is the digestion time in years

Time dependent results of a number of BMP tests are available [26-30]. The recalcitrant fraction and the hydrolysis rate of equation 1 have been fitted to these time series. There is some variability in $\mathrm{b}$ and $\mathrm{R}$ (Table 1 and 2). Cattle manure has also some variability in these constants depending of the type of fodder [31].

Table 1. Klason lignin and fraction of recalcitrant material $R$ in straw.

\begin{tabular}{lllll}
\hline Substrate & Klason lignin KL & Recalcitrant fraction R & Ratio R/KL & Author Reference \\
\hline Wheat straw & 0.24 & 0.5 & 2,0 & [35] Antonczyk \\
Wheat straw & 0.17 & 0.35 & 2,0 & [48] Dumas \\
Wheat straw & 0.18 & 0.35 & 2,0 & [49] Horvath \\
Wheat straw & 0.29 & 0.6 & 2,0 & [50] Sambusiti \\
Wheat straw & 0.27 & 0.4 & 1.5 & [51] Awais \\
Cattle manure & 0.15 & 0.25 & 1.7 & [51] Awais \\
\hline
\end{tabular}

Table 2. Recalcitrant fraction of straw and cattle manure.

\begin{tabular}{llll}
\hline Substrate & Fast tike constant $\mathbf{b ~ y}^{\mathbf{- 1}}$ & Recalcitrant fraction R & Author reference \\
\hline Wheat straw $1 \mathrm{~mm} \mathrm{AD}$ & 10 & 0.20 & [29] Slotjuk \\
Wheat straw 10 mm AD & 4 & 0.20 & [29] Slotjuk \\
Wheat straw AD & 10 & 0.35 & [30] Xavier \\
Wheat straw in soil & 1 & 0.33 & [26] Sauerbeck \\
Cattle manure slurry AD & 10 & 0.58 & [28] Kool \\
Cattle manure slurry in soil & 1 & 0.58 & [27] Verloop \\
\hline
\end{tabular}

\section{A Model for the Anaerobic Digestion of Straw}

Straw is a residue of the harvest of cereals (mainly wheat and maize) burned on the field or removed for other uses. Straw contains on average $30-45 \%$ cellulose, $20-25 \%$ hemicellulose, $15-20 \%$ lignin, as well as a number of minor organic compounds $[32,33]$.

Archaea, microbes and fungi decompose straw under aerobic conditions in the field, with the emissions of carbondioxide, trace gasses, water, and ash.

Straw plowed under releases two thirds of its carbon fixed during the growing season in the first year of decay. The other third is released in the next ten years.

Experiments on the decay of straw in the soil have been executed with radioactive labeled straw $[25,34]$. The decay of straw in the fields has been fitted with the sum of two exponential functions (a slow one and a fast one) [35]. Only the slow component with a decay constant of about eight years contributes to the SOM. Other data suggest a slow decay constant of ten to forty years [36, 37].

Straw as substrate for AD has been reported for a number of commercial facilities [9, 38-41]. The model for AD in this paper is based on four hypothesis:

During AD, the same decay process occurs as in the soil, except this process is faster, due to higher temperatures and the availability of macro and micronutrients $(\mathrm{N}, \mathrm{P}, \mathrm{Fe}, \mathrm{Zn}, \mathrm{Co}$, $\mathrm{Cu}, \mathrm{Mn}, \mathrm{Mo}, \mathrm{Ni}, \mathrm{B}, \mathrm{S}$, and $\mathrm{W}$ ) [42-45]. These nutrients are necessary for the multiplication of archaea and microbes decomposing the straw.

The decomposition of straw into carbon dioxide, methane, water and recalcitrant matter can be described by the sum of two exponential functions.

Part of the cellulose and hemicellulose is shielded by 
lignin from the attack by archaea and microbes and with lignin forms the recalcitrant matter.

The shielded part of cellulose and hemicellulose is about double that of the Klason lignin (Table 1) [37, 46-51].

In order to calculate the contribution to SOM of the effluent of the AD reactor, we assume an effective reaction time of $b t=1$. The real time depends on the efficacy of the AD process. The contribution to the SOM of straw plowed under, can be calculated assuming $\mathrm{bt}=1$ and $\mathrm{R}=0.33[25,29]$. Then, $90 \%$ of the easily degradable material (the fraction with the short decomposition time) is converted into methane, carbon dioxide and water. The recalcitrant matter in the effluent distributed on the fields contributes to the SOM. The organic matter in the effluents is:

$$
O M_{a d=} V S^{*}(1-R)^{*} e^{-c}+R^{*} e^{-d}
$$

VS is the volatile solids (organic matter) of the substrate entering the $\mathrm{AD}$ reactors

The effluent should be spread to the field where the straw has come from, and after one year in the soil, the organic matter is reduced by an extra factor of $\mathrm{e}^{-\mathrm{d}}$, neglecting the small contribution of easily degradable material:

$$
O M^{1=} V S^{*} R^{*} e^{-d_{*}} e^{-d}
$$

after $\mathrm{n}$ years in the soil, this is:

$$
O M^{n=} V S^{*} R^{*} e^{-d} * e^{-n^{*} d}
$$

After the application in each year of the same amount of organic matter, the SOM is:

$$
S O M_{a d=} V S^{*} R^{*} e^{-d} *\left(1+e^{-d}+e^{-2^{*} d}+e^{-3 d}+\ldots\right.
$$

and:

$$
\operatorname{SOM}_{a d=} V S^{*} R^{*} e^{-2 d} /\left(1-e^{-d}\right)
$$

and for: $R=0.33$ (Table 2)

$$
S O M_{a d=} V S * 2.1
$$

and:

$$
y_{C H 4=} 0.25 \mathrm{~m}^{3} / \mathrm{kg} \mathrm{VS}
$$

For straw left in the field, we obtain:

$$
S O M=V S *\left((1-R) * e^{-c}+R * e^{-d} /\left(1-e^{-d}\right)\right.
$$

and:

$$
S O M=V S * 2.5
$$

The ratio of SOM between fields fertilized by the effluent of $\mathrm{AD}$ reactors with straw as substrate and that where the straw is left to decay in the field after the harvest is:

$$
S O M_{a d} / S O M=0.85
$$

\section{A Model for the Anaerobic Digestion of Cattle Manure}

Cattle manure contains on average $15-30 \%$ cellulose, 10 $28 \%$ hemicellulose, $20-33 \%$ lignin, as well as a number of minor organic compounds [52-58].

A model from Wageningen University and Research, describes the SOM of fields, fertilised over a number of years with cattle manure [27].

This model can be simplified, to the sum of the two exponential functions and applied for the SOM of fields fertilised with the effluent of cattle manure treated by AD. with $\mathrm{R}=0.58$ equation 6 gives:

$$
S O M_{a d}=V S * 3.7
$$

For manure spread directly in the field after one year decay, (9) gives:

$$
S O M=V S * 3.8
$$

and for the ratio of SOM of fields fertilised with the effluent of $\mathrm{AD}$ reactors with manure as substrate and those fields where manure is spread without prior $\mathrm{AD}$ is:

$$
\mathrm{SOM}_{\mathrm{ad}} / \mathrm{SOM}=0.98
$$

\section{Energy Recovery by the AD of Straw}

Straw tested in Finland has a higher heating value of 17 $\mathrm{MJ} / \mathrm{kg}$ [59] and a VS content of $70 \%$. The higher heating value of VS is $24 \mathrm{MJ} / \mathrm{kg}$. The higher heating value of methane is $40 \mathrm{MJ} / \mathrm{m} 3[60]$. Energy recovery is $12 \mathrm{MJ} / \mathrm{m}^{3}$ or $50 \%$ of the higher heating value of straw.

Biomethane can be obtained by removing carbon dioxide from the $\mathrm{AD}$ gas [61]. The different upgrading methods require about $0.9 \quad \mathrm{MJ}_{\mathrm{e}} / \mathrm{m}^{3}$ methane or $1.5 \quad \mathrm{MJ}_{\mathrm{th}} / \mathrm{m}^{3}$ [62]. Combined cycle power stations using bio-methane have efficiencies of $60 \%$ [63]. The overall efficiency is $25 \%$. Direct bur- ning of straw has an efficiency of $26 \%$ [64].

The existing infrastructure for the distribution of natural gas can be used [65]. The removed carbon dioxide can be stored permanently as carbonate geologically or as biochar [66-68].

\section{Discussion}

AD reactor effluent of cattle manure slurry was applied for a period of 15 years to a field of the experimental dairy farm of Wageningen University and Research. This field showed a slight increase in SOM from $4.3 \%$ to $4.5 \%$. [69]. Control fields showed a constant SOM content over a period of 20 years [27]. No information was given about the volumes of digested cattle manure and undigested raw manure distributed to the fields. It is likely that more effluent was applied than unprocessed manure due to limitation in the 
application of N-compounds (ammonia and organic bound nitrogen).

The AD installation at that site produced in the test period $0.26 \mathrm{~m}^{3}$ methane $/ \mathrm{kg} \mathrm{VS}$ at an average retention time of 75 days [28]. BMP tests are not available, but the recalcitrant fraction is estimated, to be 0.58 assuming a hydrolysis rate for cattle manure of 10 .

Volatile fatty acids in the manure contribute to the methane yield in BLP tests, but are not measured in the VS determination [70] and in the determination of the SOM. Volatile fatty acids can be more than $10 \%$ of the VS ( depending on the storage time at the farm ) [30, 71].

In field experiments, no differences were found in the soil total $\mathrm{C}$ content after four years of application of $\mathrm{AD}$ effluent and manures [72, 73].

There is some information available of fresh and digested cattle manure after one year of decay in the soil [74, 75]. The data of Thomson et al. [74] are inconsistent as the recalcitrant fraction in digested manure should be higher than that in fresh manure. The experimental procedures, however, have not been described.

It should be noted that SOM determinations are not accurate $(>0.1 \%)$, due to analytical, spatial and temporal variations $[76,77]$.

\section{Conclusions}

Around $45 \%$ of the energy content of straw and manures can be used as a source of renewable energy. Overall, conversion efficiency to electricity is $25 \%$, compared to $26 \%$ in straw fired power stations [65].

The contribution to the soil organic matter SOM of recycled effluent is $85 \%$ of the substrates.

The AD of straw is preferred over burning of straw. The AD of agricultural residues and manures should be promoted in those regions where the SOM is higher than $2 \%$. AD of straw and manure is possible, where the SOM is lower than $2 \%$ when the loss of SOM is compensated by supplementary addition of green manures and compost [78-82].

\section{Abbreviations}

AD Anaerobic Digestion

BMP Bio Methane Potential assay

SOM Soil Organic Matter

VS Volatile Solids (Organic matter)

\section{References}

[1] Haishui Yang, A C, Jinxia Feng A, Martin Weih B et al. Yield reduction of direct-seeded rice under returned straw can be mitigated by appropriate water management improving soil phosphorus availability Crop and Pasture Science 71 (2) 134146 Year.

[2] Sanderman, J., Hengl, T. and Fiske, G. J. Soil carbon debt of 12,000 years of human land use PNAS September 5, 2017114 (36) $9575-9580$.
[3] Roper, W. R., Robarge W. P., Osmond, D. L. and Heitman, J. L. Comparing Four Methods of Measuring Soil Organic Matter in North Carolina Soils 2019 Soil Sci. Soc. Am. J. 83: 466-474.

[4] Raymond R. Weil, R. J. and Brady, N. C. Nature and Properties of Soils, 15th Edition Pearson Columbus, 2017 pages 1-1028.

[5] Lehmann J. and Kleber M. The contentious nature of soil organic matter Nature | vol 528 | December 2015 pages 60-68.

[6] Batjes, N. H. Total carbon and nitrogen in the soils of the world European journal of soil science June 199647 pages 151-163.

[7] Bot, A. and Benites, J. The importance of soil organic matter: Key to drought-resistant soil and sustained food and production. FAO soils bulletin 80. 2005 pages 1-94 Rome: Food and Agricultural Organisation; 2005.

[8] Oldfield, E. E., Bradford, M. A. and Wood, S. A. Global meta-analysis of the relationship between soil organic matter and crop yields. Soil 2019; 5, 15-32.

[9] Trivedi, A, Verma, A. R., Kaur, S., Jha, B. et al. Sustainable bio-energy production models for eradicating open field burning of paddy straw in Punjab, India. Energy 127 (2017) pages 310-317.

[10] Hendriksen, C. E. Experience with straw firing in Danish combined heat and power plants in Hackl A. (ed). Kaleidoskop Biomasse. Vienna: Österreichische Akademie der Wissenschaften:; 2018 pages 1-19.

[11] Mac an Bhaird S. T., Hemmingway P., Walsh E. et al. Bubbling fluidised bed gasification of wheat straw-gasifier performance using mullite as bed material Chemical Engineering Research and Design Volume 97, May 2015, Pages 36-44.

[12] Decorte M., Tessens S., Fernández D. et al. Mapping the state of play of renewable gases in Europe Renewable Gas trade centre in Europe Roma, Italy, 2020 pages 1-60.

[13] Sam, A., Xiang Bi, B., and Farnsworth, D. How Incentives Affect the Adoption of Anaerobic Digesters in the United States Sustainability 2017, 9, 1221.

[14] Lei Zheng, L., Jingang Chen J., Mingyue Zhao, M. et al. What Could China Give to and Take from Other Countries in Terms of the Development of the Biogas Industry? Sustainability $2020,12,1490$.

[15] Meyer, A. K. P., E. A. Ehimen, E. A., Holm-Nielsen, J. B. Future European biogas: Animal manure, straw and grass potentials for a sustainable European biogas production Biomass and Bioenergy Volume 111, April 2018, Pages 154-164.

[16] W. J. Oosterkamp Use of volatile solids from biomass for energy production in Gupta, V., Treichel, H., Kuhad, R. and Rodriguez-Couto, S. ed. Recent developments in bioenergy research Elsevier 2020, Pages 131-145.

[17] Ebertseder, T., Engels, C., Heyn, J. et al. Humusbilanzierung Eine Methode zur Analyse und Bewertung der Humusversorgung von Ackerland Verband Deutscher Landwirtschaftlicher Untersuchungs- und Forschungsanstalten (VDLUFA) Speyer, Germany. 2014 pages 1-21.

[18] Prays, N. Effects of Biogas Residues on Yield Formation and Soil Organic Carbon Stocks dissertation, Technischen Universität Berlin, 2018 Agronomy 2020, 10, 379. 
[19] Swain, F. Composition of marsh gases in the central and eastern United States Applied Geochemistry Volume 1, Issue 2, March-April 1986, Pages 301-305.

[20] Bol, J. Moeras of Brongas Grondboor en Hamer nov 1991 pages $150-153$.

[21] Chynoweth D. P. and Isaacson R. Anaerobic digestion of biomass" Elsevier Applied Science UK 1987, pages 1-278.

[22] Gunnerson, C. G., Stuckey, D. C., Greeley, M., and Skrinde, R. T. Anaerobic digestion: Principles and practices for biogas systems. United States The International Bank for Reconstruction and Development/The Worldbank, 1986 pages $1-154$.

[23] Angelidaki, I., Alves, M., Bozonella, D. et al. Defining the biomethane potential (BMP) of solid organic wastes and energy crops: A proposed protocol for batch assays, Water Sci Technol., 2009; 595: 927-934.

[24] Verdrenne, F. Beline, Dabert, P. and Bernet, N The effect of incubation conditions on the laboratory measurement of the methane producing capacity of livestock wastes " Bioresource Technology 99: 146-155-2008.

[25] Triolo, J. M., Sommer, S. G., Møller, H. B., Weisbjerg M. R. and Jiang, X. Y. "A new algorithm to characterise biodegradability of bio-matter during anaerobic digestion: Influence of lignin concentration on methane production potential. Bioresource Technology 2011; 102: 9395-9402.

[26] Sauerbeck, D. R. and Gonzalez, M. A. "Field decomposition of carbon-14-labelled plant residues in various soils of the Federal Republic of Germany and Costa Rica" in " Soil organic matter studies" in proceedings of a symposium on soil organic matter studies jointly organized by the international atomic energy agency and the food and agriculture organization of the united nations in co-operation with Agrochimica and held in Braunschweig, 6-10 september 1976, Vienna, IAEA; 1977; pp. 159-169.

[27] Verloop, J., Hilhorst, G. J., Pronk, A. A. et al. Organic matter dynamics in an intensive dairy production system on a Dutch Spodosol. Geo- derma 2015: 237-238: 159-167.

[28] A. Kool, A., Hilhorst, G. J. and van der Vegte, D. Z. "Realisatie van mestvergisting op de Marke - Onderzoek en realisatie" Rapport 50 CLM-Rapport 608-2005, CLMCulenburg, The Netherlands, 2005, pages 1-18.

[29] Slotjuk Weizenstroh verschiedene Vermahlung in $\mathrm{H}$. Oechsner ed. Forschungsinitiative und -projekte Der Landwirt als Energiewirt Biogastag Baden-Württemberg 13. März 2012, University of Hohenheim, Germany, 2012 pages 1-43.

[30] Xavier, C. A. N., Moset, V., Wahid, R., Møller, H. B. The efficiency of shredded and briquetted wheat straw in anaerobic co-digestion with dairy cattle manure. Biosystems Engineering 2015; 139: 16 - 24, 2015.

[31] Møller, H. B., Moset, V., Brask, M., Weisbjerg, M. R. and Lund $\mathrm{P}$. Feces composition and manure derived methane yield from dairy cows: Influence of diet with focus on fat supplement and roughage type. Atmospheric Environment 2014; 94: 36-43.

[32] Bakker, Wolter Elbersen, W, Poppens, R and Lesschen, J. P. Rice straw and Wheat straw Potential feedstocks for the Biobased Economy NL Agency NL Energy and Climate Change Utrecht, June 2013 pages 1-31.
[33] del Río, J. C., Rencoret, J., Prinsen, P., Martínez, A. T., Ralph, J. and Gutieŕrez A. Structural Characterization of Wheat Straw Lignin as Revealed by Analytical Pyrolysis, 2D- NMR, and Reductive Cleavage Methods J. Agric. Food Chem. 2012, $60,5922-5935$.

[34] Beyaert, R. P. and Voroney, R. P. Estimation of decay constants for crop residues measured over 15 years in conventional and reduced tillage systems in a coarse-textured soil in southern Ontario. Canadian journal of soil science 2011: 91 (6): 985-995.

[35] Antonczyk, S. R. Arthur, R. and P. Scherer, P. Straw as a Sustainable Farm-Based Feedstock for Biogas. Proceedings EBA Workshop; 2017; Brussels Belgium: European Biogas association 2017, pages 1-23.

[36] De Haan, S. "Humus, its formation, its relation with the mineral part of the soil, and its significance for soil productivity (IASM-211/12) IAEA Vienna, Austria, 1977 pages 10-21.

[37] Heim, A. and Schmidt, M. W. I. Lignin is not a main contributor to the stable soil organic carbon fraction Soil Science and Biogeography Group, Department of Geography, University of Zurich, Switzerland, 2005 pages 1-2.

[38] H. Dauser, "Economic Considerations of the Straw Preparation Agents de Economizer Technology using the example of biogas plants in the UK", in R. Heizel ed. Tagungsband Biogas aus Stroh Hildesheim, ProFair consult+ Project GmbH, 2017, pp 69-72.

[39] Oechsner, H."2012. Forschungsinitiative und -projecte zur bio- gasforschung. In: Kranert, M. (Ed.), 8e Biogastag Baden Wuertenberg 13 Maerz 2012 Hohenheim. Essen, Oldenbourg Industrie Verlag, 2012, pp. 1-144.

[40] Sherrard, A. "Breaking the straw to biogas conundrum", Bioenergy International, June 2016.

[41] Fink, J."Anaerobic Digestion of High Solid Material like Farm Yard Manure", Xergi, Støvring- Danmark. no date, pages 1-22.

[42] Arikan, A., Mulbry, W., and Lansing, S. Effect of temperature on methane production from field-scale anaerobic digesters treating dairy manure Waste Management 43 (2015) pages 108-113.

[43] Jerger, D. E., Conrad, J. R., Fannin, K. F., Cynoweth, D. P., 1982. Bio- gasification of woody biomass. In: White, J. W., McGrew, W., Sutton, M. R. (Eds.), Energy from Biomass and Wastes VI. Institute of Gas Technology, Chicago Il, USA, pages 341-372.

[44] Scherer, P. 2011 "Wirkungsweise von Spurenelementen in der Biovergasungskette" Fachtagung "Spurenelementen in Biogasanlagen” Energie Agentur Götingen Germany, 2011, pages $1-48$.

[45] Engler, N. Spurenelementkonzentrationen und biologische Aktivität in NaWaRo- Biogasfermentern" Dissertation Universität Rostock, Germany 2015 pages 1-107.

[46] Ritter; J., Seborg, R. M and Mitchell, R. L. Factors affecting quantitative determination of lignin 72 percent sulfuric acid method Ind. Eng. Chem. Anal. Ed. 1932, 4, 2, 202-204.

[47] Klason P. Contributions to a more exact knowledge of the chemical composition of spruce wood, part I. Pap. Trade J. 1922, 74 (18), 45-51. 
[48] Dumas, C., Silva Ghizzi Damascenoc, G., Barakatc, A., H. Carrèrea, H J-P. Steyera, J-P and Rouauc, X. Effects of grinding processes on anaerobic digestion of wheat straw Industrial crops and products 2015: 74: 450-456.

[49] Horváth, I. S., del Pilar Castillo, M., Schnürer, A., Agnihotri, S., Ylitervo, P. and Edström, M. Utilization of straw pellets and briquettes as co-substrates at biogas plants Stockholm Sweden: Energiforsk AB 2015 pages 1-62.

[50] Sambusiti, C. Physical, chemical and biological pretreatments to enhance biogas production from lignocellulosic substrates Milan, Italy: Politecnico di Milano, 2013 pages 1-206.

[51] Awais, M., Alvarado-Morales, Tsapekos, P., Gulfraz, M. and Angelidaki, I. Methane Production and Kinetic Modeling for Co-digestion of Manure with Lignocellulosic Residues Energy Fuels 2016, 30, 12, 10516-10523.

[52] Hindrichsen, I. K., Kreuzer, M., Madsen, J. and Bach Knudsen, K. E. Fiber and Lignin Analysis in Concentrate, Forage, and Feces: Detergent Versus Enzymatic-Chemical Method Dairy Sci. 89: 2168-2176-2016.

[53] Yang, Q, Wang, H., Larson, R., and Runge T. Comparative Study of Chemical Pretreatments of Dairy Manure for Enhanced Biomethane Production BioResources 201712 (4), 7363-7375.

[54] Kumar, P., Barrett, D. M., Delwiche, M. J., Stroeve, P. 2009. Methods for pretreatment of lignocellulosic biomass for efficient hydrolysis and biofuel production. Industrial \& Engineering Chemistry Research, 48 (8), 3713-3729.

[55] Liao, W., Liu, Y., Liu, C., Wen, Z., Chen, S. 2006. Acid hydrolysis of fibers from dairy manure. Bioresource Technology, 1687-1695.

[56] Wen, Z., Liao, W., Chen, S. 2004. Hydrolysis of animal manure lignocellulosics for reducing sugar production. Bioresource Technology, 91, 31-39.

[57] Joute, Y., el Bari, H. - Belhadj, S. Semi-continuous anaerobic co-digestion of cow manure and banana waste: effects of mixture ratio Applied ecology and environmental research 14 (2): $337-349$

[58] Wilen, C., Moilanen, A. and Kurkula, E. Biomass feedstock analyses VTT publications 282 Espoo 1996 pages 1-4.

[59] Waldheim, L. and Nilsson, T. Heating values from gases of biomass gasification TPS 01/16 TPS Thermiska Processer AB Nyköping, Sweden pages 1-60.

[60] Cappannelli, M., McGlade, C. and Peter Zeniewski, P. Outlook for biogas and biomethane IEA Paris, 2020, p 1-93.

[61] Hoyer, K. Hulteberg, C,. Svensson, M., Jernberg, J., and øyvind Nørregård, Ø. Biogas Upgrading - Technical Review 2016 Energiforsk report 2016: 275 Sweden pages 1-75.

[62] Waardenburg, I. Diemen-34 levert eerste stroom, Technisch weekblad 2012 pages 1-2.

[63] Pieper, M. Errichtung eines strohbefeuerten Heizkraftwerkes BEKW Bioenergiekraftwerk Emsland BEKW Bioenergiekraftwerk Emsland, Emlichheim Germany 2016, pp 1-96.

[64] Urban, W. Biomethane injection into natural gas networks ch 16 in Wellinger, A., Murphy J. and Baxter D. The Biogas Handbook Science, Production and Applications Woodhead Publishing Series in Energy 2013 pages 378-403.
[65] Gunnarsson, I., Aradóttir E. D., Oelkers, E. H. et al. The rapid and cost-effective capture and subsurface mineral storage of carbon and sulfur at the CarbFix2 site International Journal of Greenhouse Gas Control Volume 79, Dec. 2018, Pages 117126.

[66] Verduyn, M., Geerlings, H. and van Mossel, G. Review of the various $\mathrm{CO} 2$ mineralization product forms Energy Procedia 4 (2011) 2885-2892.

[67] Gupta D. K. et al. (2020) Role of Biochar in Carbon Sequestration and Greenhouse Gas Mitigation. In: Singh J., Singh C. (eds). Biochar Applications in Agriculture and Environment Management. Springer, Cham.

[68] van der Vegte, Z. Bodemkwaliteit neemt niet af op De Marke. Wageningen: Wageningen University and Research 2016.

[69] Vahlberg, C., Nordell, E., Wiberg, L., and Schnürer, A., "Method for correction of VFA loss in determination of dry matter in biomass" Svenskt Gastekniskt Center, Malmö, Sweden, 2013 pages 1-50.

[70] Timmerman, M, de Boer, H. C., Verdoes, N. and Schilder, H. Effect van vergisting op het orthofosfaat gehalte in rundermest en potentieel voor terugwinning Wageningen Livestoch Research, Wageningen, the Netherlands, 2018 pages 1-53.

[71] Barłóg P, Hlisnikovsk, L. and Kunzová E. Effect of Digestate on Soil Organic Carbon and Plant-Available Nutrient Content Compared to Cattle Slurry and Mineral Fertilization Agronomy 2020, 10, 379.

[72] Möller, K. Effects of biogas digestion on soil organic matter and nitrogen inputs, flows and budgets in organic cropping systems. Nutr Cycl Agroecosyst 2009 84: 179-202.

[73] Thomsen, I. K., Olesen, J., Møller, H. B., Sørensen, P., Christensen, B. T Carbon dynamics and retention in soil after anaerobic digestion of dairy cattle feed and faeces. Soil Biol. Biochem 2013; 58: 82-87.

[74] Veeken, A., F. Adani, F., D. FangueiroD., and L. Stoumann JensenL. The value of recycling organic matter to soils EIPAGRI Focus Group - Nutrient recycling Brussels Belgium: European Commission 2017.

[75] Körschens M, Der organische Kohlenstoff im Boden (Corg) Bedeutung, Bestimmung, Bewertung Soil organic carbon (Corg) - importance, determination, evaluation Archives of Agronomy and Soil Science Vol. 56, No. 4c, August 2010, 375-392.

[76] Körschens M, Spitzl M. 1978. Methodische Untersuchungen zur Bestimmung des $\mathrm{Ct}$ - und $\mathrm{Nt}-$ Gehaltes im Boden. Arch. Acker- u. Pflanzenbau u. Bodenkd., Berlin. 22 (11): 705-711.

[77] Rogasik J, Körschens M, Rogasik H, Schnug E. 2007. CSequestrierungspotentiale Agrarisch genutzter Böden in Deutschland. In: Hüttl RF, Prechtel A, Bens O. Humusversorgung von Böden in Deutschland. Forschungsprojekt im Auftrag des Umweltbundesamtes, FuEVorhaben Förderkennzeichen 36013008.

[78] Baumecker M, Ellmer F, Kohn W. 2009. Statischer Nährstoffmangelversuch Thyrow. Dauerfeldversuche in Brandenburg und Berlin, Beiträge für eine nachhaltige landwirtschaftliche Bodennutzung. Herausgeber: Ministerium für Landliche Entwicklung, Umwelt und Verbraucherschutz, Potsdam. S. 129. 
[79] Vander Linden, A. M. A., Van Veen, J. A. and Frissel, M. J. Modelling soil organic matter levels after long-term applications of crop residues, and farmyard and green manures. Plant Soil 101, 21-28 (1987).

[80] Koopmans C. and Bloem J. Soil quality effects of compost and manure in arable cropping Louis Bolk Institute 2018, Bunnik, Netherlands.
[81] Witing, F., Gebel, M., Kurzer, H. J., Friese, H. and Franko, U. Large-scale integrated assessment of soil carbon and organic matter-related nitrogen fluxes in Saxony (Germany) Journal of Enviriomnetal Management 237 (2019) 272-280. 